\title{
ERRORS IN THE EMERGENCY ASSESSMENT OF PEDIATRIC HEAD TRAUMA DURING THE CORONAVIRUS PANDEMIC: A REPORT OF TWO CASES
}

\section{Koronavirüs Pandemisi Sırasında Pediatrik Kafa Travmasının Acil Değerlendirmesindeki Hatalar: İki Vaka Sunumu}

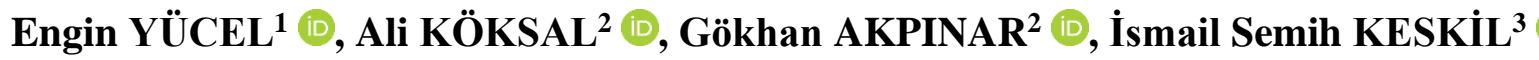

${ }^{I}$ Republic of Turkey Ministry of Health Alanya ER Hospital, Department of Neurosurgery, ANTALYA, TÜRKIYYE

${ }^{2}$ Bayındır Hospital, Department of Radiology, Söğ̈̈tözü, ANKARA, TÜRKIYE

${ }^{3}$ Yüksek Ihtisas University, Department of Electroneurophysiology, ANKARA, TÜRKIYE

\section{ABSTRACT}

ÖZ

The coronavirus pandemic has posed a challenge to healthcare workers, who are at high risk for exposure to the disease. However, they also face the risk of infection due to the presence of asymptomatic carriers. The aim of this study was to demonstrate the necessity of a standard radiography protocol for fracture surveillance and good history taking and physical and neurological examinations, especially in pediatric patients with minor head injuries and negative routine non-contrast computed tomography results. We think that abandoning radiography in minor head-injury assessments is not right at the moment. Head injuries can be safely managed using a combination of skull radiography and three-dimensional reconstruction and thin-slice bone-imaging window computed tomography.

Keywords: Pediatric skull fracture, three-dimensional computed tomography, craniography, COVID-19 pandemic, emergency room
Koronavirüs hastalığ1 salgını, hastalığa maruz kalma riski yüksek olan sağlık çalışanları için bir zorluk oluşturdu. Bununla birlikte, sağlık çalışanları semptomsuz taşıyıcıların varlığı nedeniyle enfeksiyon riskiyle de karşı karşıya kalmaktadırlar. $\mathrm{Bu}$ çalışmanın amacı, özellikle minör kafa travması ve negatif rutin kontrastsız bilgisayarlı tomografi sonuçları olan pediatrik hastalarda; ayrıntılı öykü alma, ayrıntılı fiziksel nörolojik muayeneler, kafatası kırığı tanısı koyma ve takibi için standart bir radyografi protokolünün gerekliliğini hatırlatmaktır. Hafif kafa travması değerlendirmelerinde radyografiyi terk etmenin şu anda doğru olmadığını düşünüyoruz. Kafa yaralanmalı hastaların yönetimi, kafatası konvansiyonel radyografisi, üç boyutlu rekonstrüksiyonu ve ince kesitli kemik görüntüleme pencereli bilgisayarlı tomografi kombinasyonu kullanılarak güvenli bir şekilde yapılabilir.

Anahtar Kelimeler: Çocuklarda kafa kırı̆̆l, üç boyutlu bilgisayarl tomografi, kraniografi, COVID-19 pandemisi, acil servis 


\section{INTRODUCTION}

Although the number of patients admitted to emergency departments has significantly decreased during the coronavirus disease (COVID-19) pandemic, health-care workers tend to avoid conducting detailed examinations on patients because of the risk of contracting COVID19 from asymptomatic carriers despite taking thorough personal protective measures (1-3). In fact, health workers are advised to get tested at regular intervals considering their potential as asymptomatic COVID-19 carriers $(2,4)$. The COVID-19 pandemic outbreak has blindsided the world, forcing a change in many diagnostic and treatment algorithms (5). Under these conditions, most emergency physicians tend to initially send patients with skull traumas to undergo computed tomography (CT). Among the reasons for such a change, those frequently reported were the reluctance of health workers to have close physical contact with patients and the eagerness of patients and the persons accompanying them to leave the emergency ward as quickly as possible.

\section{CASE REPORTS}

Case 1. An 8-year-old boy was admitted to the emergency department 30 minutes after falling from a bicycle, with a GCS score of 15 . He had no neurological deficit, a $2 \mathrm{~cm}$ parietal cephalic hematoma, and a simple skull fracture that was beyond the surgical margins (Fig. 1). The direct skull radiograph obtained as a legally mandated practice in our country revealed a comminuted fracture (Fig. 1). He underwent operation in accordance with the finding that the broken thin inner tabulae piece had pierced the dura, causing a cerebrospinal fluid leak. Three-dimensional reconstruction (3-D) images are always preferred in cases where further injuries are suspected (Fig. 1)

Case 2. A 12-year-old boy was admitted to the emergency department after falling down from a short height, with a GCS score of 15 . He had no neurological deficit but had a $6 \mathrm{~cm}$ bilateral cephalic hematoma. His CT scan showed no abnormalities (Fig. 2). However, the direct skull radiograph, obtained as a legally mandated practice in our country, showed a bilateral separated fracture (Fig. 2).

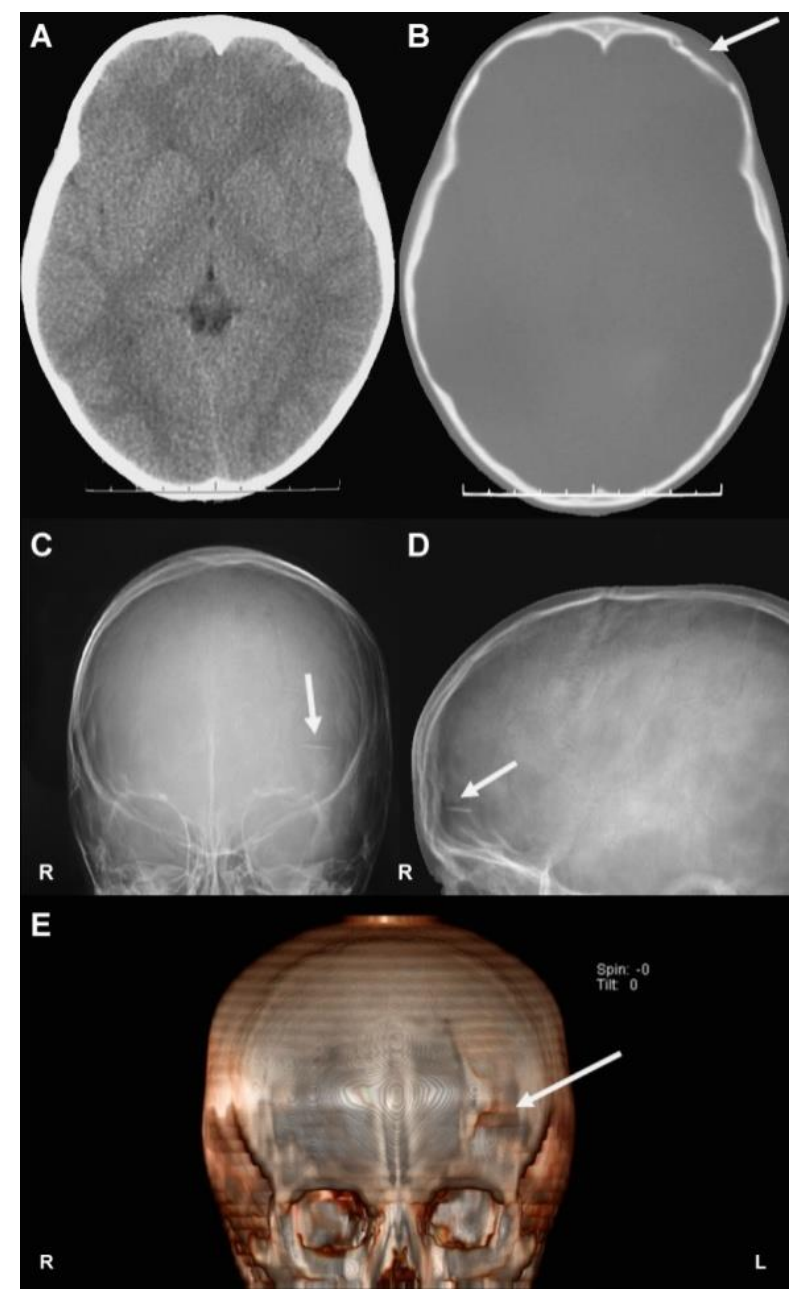

Fig. 1: Computed tomography (CT) scan of a simple skull fracture outside the surgical margin and skull radiograph showing the spiked bone piece of the fracture that is almost parallel to the CT slices. Threedimensional reconstruction image.

\section{DISCUSSION}

The cases of low and moderate intensity head traumas could not be distinguished because of the reluctance of health workers to have close physical contact with the patients during the COVID-19 pandemic; the concern of patients and the persons accompanying them about 
getting infected, which made them impatient to leave the emergency ward as quickly as possible; and the lack of complete anamnesis in the obtained medical histories. In addition, the cases were primarily evaluated on the basis of brain tomography findings against the possibility of an intracranial pathology. However, because all fall injuries are regarded as judicial cases and required craniography examination in our country, these examinations were indeed conducted after tomography. As a result, a fracture case, which could not be identified on the said CT image, was therefore diagnosed.

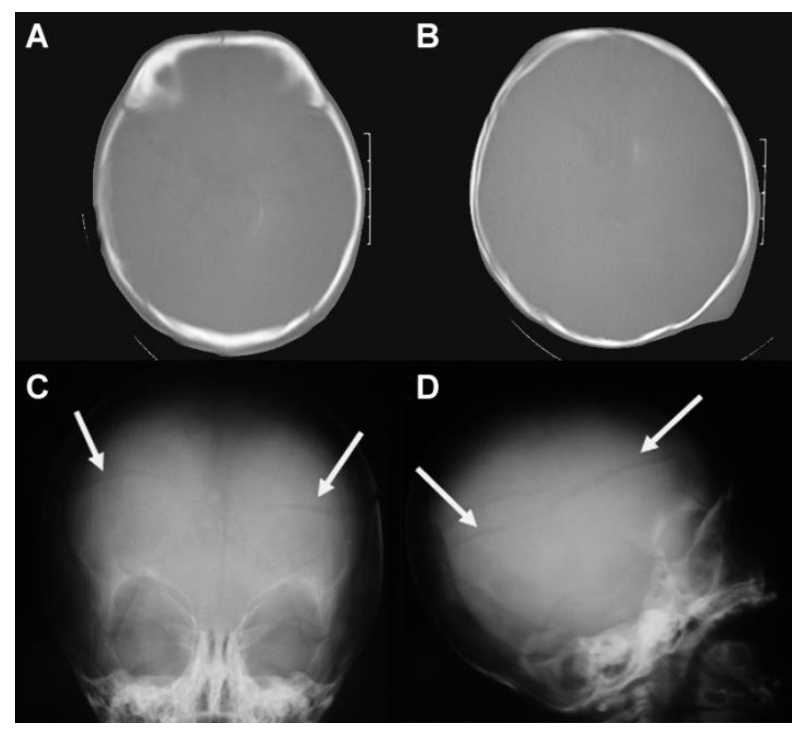

Fig. 2: Two most suspicious bone window computed tomography (CT) scan and skull radiograph showing the bilateral separated fracture that is almost parallel to the CT slices.

Our patients are MHT cases whose complicated fractures were not demonstrated on the CT scans, except for one patient who had a simple non operative fracture. It is a common issue that bony injuries parallel to the standard CT slices are not demonstrated on CT images; thus, three-dimensional images are always preferred in cases where further injuries are suspected. Our patient (Case 1) with a depressed fracture that lacerated the dura could develop a late sequela if it had remained undiagnosed. Considering the increased harmful effects of radiation on children, the diagnosis must be concluded with the fewest possible number of radiological tests (6). Considering these two index cases, we believe that abandoning radiography in the MHT assessment is not advisable at the moment. Furthermore, head injuries have been shown recently to be safely managed using a combination of skull radiography and limited CT scanning (7).

\section{CONCLUSION}

Linear head fractures in children can be missed. Especially in the COVID pandemic, avoiding direct contact with patients and the tendency to allocate less time to patients due to contamination anxiety increased the risk of overlooking the diagnosis of pediatric head trauma. In pediatric patients with MHT, we draw attention to this situation and to the realization of the necessary measures that should be taken in the light of this information.

Conflict of Interest: All authors declare no conflicts of interest with respect to the authorship and/or publication of this article.

Researchers' Contribution Rate Statement: All authors made substantial contributions to the following: study design EY; data acquisition AK, analysis, and interpretation EY; manuscript preparation EY, and final manuscript approval İSK.

Support and Thanks: The study does not have any financial support. Thanks to Turkish Neurosurgical Society for their support.

Informed Volunteer / Consent Form: Surgical preintervention routine informed consent form taken. 


\section{REFERENCES}

1. Butt AA, Azad AM, Kartha AB, Masoodi NA, Bertollini R, Abou-Samra AB. Volume and acuity of emergency department visits prior to and after COVID-19. J Emerg Med. 2020;59(5):730-4.

2. Tan L, Kovoor JG, Williamson P, Tivey DR, Babidge WJ, Collinson TG et al. Personal protective equipment and evidence-based advice for surgical departments during COVID-19. ANZ J Surg. 2020;90(9):1566-72.

3. Atkinson P, French J, Lang E, McColl T, Mazurik L Just the Facts: Protecting frontline clinicians during the COVID-19 pandemic. CJEM. 2020;22(4):435-9.

4. Treibel TA, Manisty C, Burton M, McKnight Á, Lambourne J, Augusto JB et al. COVID-19: PCR screening of asymptomatic health-care workers at London hospital. Lancet. 2020;395(10237):1608-10.

5. Babidge WJ, Tivey DR, Kovoor JG, Weidenbach K, Collinson TG, Hewett PJ et al. Surgery triage during the COVID-19 Pandemic. ANZ J Surg. 2020;90(9):1558-65.

6. Scaife ER, Rollins MD: Managing radiation risk in the evaluation of the pediatric trauma patient. Semin Pediatr Surg. 2010;19(4):252-6.

7. Macgregor DM, McKie L. CT or not CT-that is the question. Whether 'tis better to evaluate clinically and $\mathrm{x}$ ray than to undertake a CT head scan! Emerg Med J. 2005;22(8):541-3. 